\title{
Induced lactation in pubertal heifers: Efficacy, response to bovine somatotropin, and profitability
}

\author{
A. L. Macrina, ${ }^{1}$ P. R. Tozer, ${ }^{2}$ and R. S. Kensinger ${ }^{3}$ \\ Department of Dairy and Animal Science, The Pennsylvania State University, University Park 16802
}

\begin{abstract}
Heifer rearing represents one of the largest costs of commercial dairying because these animals do not begin to produce milk until approximately $2 \mathrm{yr}$ of age. The objectives of this study were to characterize milk production, growth, reproduction, and herd life after induced lactation in healthy 15-mo-old heifers. We further wanted to quantify their lactation response to bovine somatotropin (bST), and compare survival rate and profitability of heifers induced into lactation to that of heifers reared using traditional methods. Holstein heifers $(\mathrm{n}=32)$ were induced into lactation by administration of estradiol- $17 \beta(0.075 \mathrm{mg} / \mathrm{kg}$ of body weight per $\mathrm{d})$ and progesterone $(0.25 \mathrm{mg} / \mathrm{kg}$ of body weight per d) for $7 \mathrm{~d}$. Milking began on experimental d 18. Heifers were paired based on milk production, and one in each pair was assigned randomly to bST or control treatment groups; treatments began on $25 \pm 7$ $\mathrm{d}$ of lactation, and milk production was compared for 70 d. Heifers treated with bST produced $14.7 \%$ more milk than did controls. After the 70-d comparison period, all heifers received bST for the remainder of their lactations. Throughout the induced lactation, heifers gained $0.69 \mathrm{~kg} / \mathrm{d}$, averaged 1.8 services/pregnancy, and 27 heifers calved for a second lactation. For the herd life and economic analyses, heifers induced into lactation were compared with similarly aged heifers in the same herd reared by traditional management methods. The animals induced into lactation had a $62.7 \%$ chance of remaining in the herd as long as the peer cohorts, but both groups had similar productive lifespans. Net present value for an induced animal $(\$ 2,459)$ was not different from that of a traditionally raised peer $(\$ 3,137)$. In summary, heifers hormonally induced into lactation with estrogen and progesterone were healthy,
\end{abstract}

Received September 10, 2010.

Accepted December 10, 2010.

${ }^{1}$ Corresponding author: ALM106@psu.edu

${ }^{2}$ Current affiliation: PRT Consulting, 264 Neeld St., West Wyalong, NSW, Australia, 2671.

${ }^{3}$ Current affiliation: Department of Animal Science, Oklahoma State University, Stillwater 74074. grew normally, had a mean daily milk production of $18 \mathrm{~kg}$ with normal composition, and had good reproductive performance. Based upon the assumptions and prevailing financial environment of this experiment, hormonally induced lactation of 15-mo-old heifers, as a routine management tool, was not more profitable than traditional management practices.

Key words: induced lactation, dairy heifer, economics, herd life

\section{INTRODUCTION}

Heifer rearing represents one of the largest costs of dairying because these animals do not begin to produce milk until approximately $2 \mathrm{yr}$ of age. Until that time, they cost the dairy producer money for feed, housing, and management. Heinrichs (1996) reported that it requires 25 to $26 \mathrm{mo}$ and rearing costs of $\$ 1,150$ to $\$ 1,350$ to bring a single heifer into production. If heifers produced milk earlier in life, they could generate revenue instead of exclusively consuming resources. Some dairy producers breed heifers for a first calving at 21 or 22 mo of age. This can be problematic if heifers are not large enough and experience calving difficulties. Also, this only brings the heifer into production a few months earlier. Consequently, the potential to decrease the amount of non-milk-producing time using earlier breeding and parturition in heifers is limited. Thus, a method to induce lactation in heifers at a much younger age might increase net income of producers.

Induced lactation using estrogen in heifers was first reported by Walker and Stanley (1941). Subsequently, numerous induced lactation studies in both cows and heifers were conducted (Malpress, 1947). The protocols were long, however, requiring up to 9 mo of treatment, and employed large doses of hormones. Smith and Schanbacher (1973) showed that lactation could be induced using a 7 - $d$ treatment period of estradiol-17 $\beta$ and progesterone. Subsequent research confirmed the feasibility of inducing lactation in nonpregnant cows and heifers using a shortened protocol (Collier et al., 1975; Kensinger et al., 1979; Byatt et al., 1994; Magliaro et al., 2004). Most of these studies were conducted on 
animals with documented reproductive failure. Nonetheless, they did demonstrate that induced lactation using this protocol was possible in heifers.

As observed in cows, induced lactation in heifers resulted in variable milk yield responses among individual animals (Smith and Schanbacher, 1974; Harness et al., 1978; Byatt et al., 1997). Peak milk yields ranged from approximately $7 \mathrm{~kg} / \mathrm{d}$ (Fulkerson, 1978) to over $20 \mathrm{~kg} / \mathrm{d}$ (Smith and Schanbacher, 1974) in heifers that produced milk following the induction protocol. Success rate of induced lactation varied among studies. Smith and Schanbacher (1974) reported that $62 \%$ of the heifers induced into lactation in their study produced milk, while Harness et al. (1978) reported a 92\% success rate. Fulkerson (1978) induced lactation in reproductively normal heifers and reported that all animals successfully lactated; however, milk production was only 60 to $70 \%$ of the milk observed in postpartum lactations. Efforts to improve milk yields in animals induced into lactation have been hampered by large animal-toanimal variation. Administration of dexamethasone, reserpine, placental lactogen, or thyrotropin-releasing hormone has resulted in inconsistent responses (Collier et al., 1975; Fulkerson, 1978; Peel et al., 1978; Jordan et al., 1981; Byatt et al., 1997). However, cows induced into lactation and treated with bST produced more milk than animals induced into lactation that did not receive bST (Magliaro et al., 2004). Byatt et al. (1997) observed an increase in milk production when heifers induced into lactation were treated with bST over a 10-d period, but a control group was not available for comparison. It is unknown if heifers induced into lactation treated with bST would maintain this increased production with longer-term treatment. The present experiment is the first controlled study to investigate milk production responses to bST in heifers hormonally induced into lactation.

In order for any technology to be adopted as a management tool, it must be profitable. It is not clear if induced lactation in heifers would be economically advantageous over traditional rearing and calving around 24 mo of age. Magliaro et al. (2004) reported a $\$ 520 /$ cow economic advantage of inducing a cow into lactation rather than replacing her with a heifer calving for the first time. In this comparison, the cost of raising a heifer from birth to calving at approximately 24 mo represents a significant expense to the producer. Heifers induced into lactation at 15 mo would begin lactating about 9 mo earlier than traditionally-reared animals. Lormore and Galligan (2001) used mathematical modeling to explore the potential economic feasibility of various atypical lactation regimens including induced lactation. They estimated the potential advantage of inducing heifers to lactate at 12 mo of age based on data of Kensinger (2000) who reported milk production of $17.8 \mathrm{~kg} / \mathrm{d}$ over $300 \mathrm{~d}$ for heifers induced into lactation at 15 mo of age. Inducing heifers at 12 mo would decrease the negative cash flow over the growth period and could improve profitability if heifers produced at $79 \%$ of expected levels and culling was less than $46 \%$ annually (Lormore and Galligan, 2001). Decreasing an animal's nonproductive time in the herd and use of bST in heifers induced into lactation has potential to improve profitability. However, it is unknown how inducing lactation at an early age affects growth, subsequent reproduction, lifetime milk production, and survival rate.

Most studies on induced lactation in heifers have been problematic. They used relatively few animals, used older infertile animals, and/or collected data for a limited period of time. Therefore, the objectives of the present study were to characterize induced lactation in healthy 15-mo-old heifers, quantify their milk yield response to bST, and determine herd survival rate and profitability.

\section{MATERIALS AND METHODS}

Healthy Holstein heifers (15 mo of age; $\mathrm{n}=32$ ) with a mean body weight of $427 \pm 41 \mathrm{~kg}$ (mean $\pm \mathrm{SD}$ ) and mean BCS of $3.6 \pm 0.2$ (mean $\pm \mathrm{SD}$ ) were induced into lactation. Estrous cycles were synchronized using norgestomet ear implants with intramuscular injections of estradiol valerate and progesterone (Synchro-MateB, Sanofi Animal Health, Inc., Overland Park, KS) so that all heifers would be in a similar phase of the cycle upon induction of lactation. They were induced in 4 different groups with 8 heifers/group beginning on $\mathrm{d} 6.0 \pm 1.8$ of the estrous cycle. Heifers received daily subcutaneous injections of estradiol-17 $\beta$ (0.075 $\mathrm{mg} / \mathrm{kg}$ of BW; E-8875, Sigma-Aldrich, St. Louis, MO) and progesterone $(0.25 \mathrm{mg} / \mathrm{kg}$ of BW; P-0130, SigmaAldrich) for $\mathrm{d} 1$ to 7 of the experiment. The hormone solution was prepared in absolute ethanol to achieve $15 \mathrm{mg}$ of estradiol- $17 \beta / \mathrm{mL}$ and $50 \mathrm{mg}$ of progesterone/ $\mathrm{mL}$. During the induction phase of the study, animals were housed in a climate-controlled barn in individual tie stalls to prevent injury due to estrous-like behavior associated with the estrogen/progesterone treatment.

Milking began on d 18 of the experiment and heifers were milked once per day until production reached approximately $3 \mathrm{~kg}$. Thereafter, milking was conducted twice daily until animals returned to the main university herd at $18 \pm 1 \mathrm{~d}$ of lactation. They were then milked 2 or 3 times daily according to current herd management practice in place at the time. Heifers in the first group were milked twice daily through d 78, then switched to 3 milkings per day. Animals in all other groups were 
Table 1. Diet composition and analyses for representative diets used

\begin{tabular}{lcc}
\hline Item & $\begin{array}{c}\text { Dry } \\
\text { cow TMR }\end{array}$ & $\begin{array}{c}\text { Lactating } \\
\text { cow TMR }\end{array}$ \\
\hline Ingredient, \% of DM & & \\
Alfalfa hay, chopped & - & 5.8 \\
Alfalfa hay silage & - & 41.8 \\
Grass hay, chopped & 20.2 & - \\
Grass hay silage & 19.5 & - \\
Corn silage & 35.3 & 22.0 \\
Corn meal & - & - \\
Ground corn & 7.0 & - \\
Canola meal & 7.5 & 2.6 \\
Soybeans, cooked & & 5.8 \\
Distillers grain & 5.4 & 2.9 \\
Wheat middlings & 2.5 & 1.7 \\
Soy hulls & - & 0.29 \\
Dicalcium phosphate & - & 0.32 \\
Limestone & 0.38 & 0.26 \\
Salt & 0.22 & 1.4 \\
Vitamin/mineral mix & 2.0 & 54.0 \\
Composition & & 17.6 \\
DM, \% & 42.8 & 21.5 \\
CP, \% & 14.5 & 33.6 \\
ADF, \% & 26.3 & 0.95 \\
NDF, \% & 41.3 & 0.50 \\
Ca, \% & 0.58 & 1.65 \\
P, \% & 0.39 & \\
NE, Mcal/kg of DM & 1.60 & \\
\hline
\end{tabular}

milked 3 times daily upon return to the herd. Three times daily milking continued until midlactation (d 236 $\pm 41)$ and animals were milked twice daily thereafter until dry off.

Heifers within each group were paired based on milk production during the first $18 \mathrm{~d}$ of lactation. Within each pair, heifers were assigned randomly to either bST or control treatment. Pairs were managed identically during this portion of the experiment. Each pair commenced bST or control treatment on d $25 \pm 7$ of lactation. The reason for variation in the start of the bST treatment period was that the $\mathrm{bST} /$ control comparison did not begin until the next herd bST treatment day, which could be 1 to $13 \mathrm{~d}$ after their return to the herd. Bovine somatotropin (Posilac, Monsanto Co., St. Louis, MO) was administered every 2 wk for 10 wk. During this time, there were 2 DHIA test days to determine milk composition. After the 70-d bST/control treatment comparison, all animals induced into lactation received bST every 2 wk. Daily milk yield and monthly milk composition data were collected for the entire lactation. Heifers also were weighed monthly to monitor growth. One heifer was removed from the study on d 15 of milking because of a chronic urinary tract infection.

Prior to initiation of lactation, animals were fed a TMR designed to meet the NRC requirements of lategestation dairy cows (NRC, 1989). Two days before milking commenced (treatment d 16), heifers received a mixture containing equal parts of the dry cow TMR and a lactating cow TMR. Once milking began, animals received the lactating cow TMR ad libitum. They continued to receive the same lactating cow TMR in freestall housing upon their return to the Penn State University dairy herd. Diet compositions presented (Table 1) are representative of those fed over the course of this research. This experiment was approved by the Institutional Animal Care and Use Committee at the Pennsylvania State University.

Data for response to bST were analyzed using the Mixed procedure of SAS (Statistical Analysis System, Cary, NC). For the bST/control treatment comparison, the model included treatment, group, day of treatment, and first-order interactions. Subject was heifer (treatment $\times$ group), and treatment day was used as the repeated measure with an autoregressive type 1 covariance matrix.

Heifers induced into lactation also were compared with peer heifers in the Penn State University herd. Prior to the start of the experiment, a peer heifer cohort was selected for each of the 32 study heifers, based upon similar date of birth. The age-matched peer for an induced heifer removed from the experiment also was eliminated from the study. The peer heifers were housed in a freestall barn and were fed rations formulated to meet the NRC requirements for dairy heifers (NRC, 1989). Peer heifers were bred starting at approximately 15 mo of age. After calving, all peer heifers received bST beginning on the first herd treatment day $\geq 60$ DIM according to routine herd management protocol. Monthly milk yield and composition and reproduction data were collected for the heifers induced into lactation and the peer heifers for their entire herd lives. Once the animals were in the milking herd, induced heifers and peer heifers were subject to the same routine herd management protocols regarding milking, breeding, and health care. Heifers induced into lactation and peer heifers in their first lactations were eligible for breeding after a 50-d voluntary waiting period. Proc Mixed was used to analyze reproductive data, and Proc Freq was used to determine if incidence of calf mortality was different between induced and peer animals.

For the economic analyses, data from induced and peer animals were collected until they reached 60 mo of age. This timeframe represents 3 lactations, which is the average herd life for Holstein cows in Pennsylvania. The economic analysis included a determination of monthly income over costs for each animal, and then a calculation of the present value of the stream of those net incomes. Present value analysis was used to account for differences in the timing of onset of milk production and cull income in addition to other income and 
Table 2. Economic parameters used in the present value analysis

\begin{tabular}{ll}
\hline Component & $\begin{array}{l}\text { Economic } \\
\text { value }\end{array}$ \\
\hline Milk producer price differential $(\mathrm{PPD})$ & $\$ 0.044 / \mathrm{kg}(\$ 1.98 / \mathrm{cwt})^{1}$ \\
Milk fat & $\$ 3.06 / \mathrm{kg}(\$ 1.39 / \mathrm{lb})$ \\
Milk protein & $\$ 4.36 / \mathrm{kg}(\$ 1.98 / \mathrm{lb})$ \\
Milk hauling & $\$ 0.0002 / \mathrm{kg}(\$ 0.01 / \mathrm{cwt})$ \\
Daily feed cost for lactating animals & \\
Daily feed cost for bred heifers & $\$ 3.89 / \mathrm{cow}$ \\
Daily feed cost for dry cows & $\$ 3.00 / \mathrm{cow}$ \\
Induction treatment cost & $\$ 20 /$ animal \\
bST treatment cost & $\$ 5.15 / \mathrm{cow}$ \\
Artificial insemination cost & $\$ 23 / \mathrm{breeding}$ \\
Discount factor & $5 \%$ \\
\hline
\end{tabular}

${ }^{1}$ Milk and component prices from Federal Milk Marketing Order 1 [USDA-Agricultural Marketing Service (AMS), 2010].

${ }^{2}$ Assumed the cost would be the same as for lactating cows in the herd consuming $25 \mathrm{~kg}$ of $\mathrm{DM} / \mathrm{d}$.

${ }^{3}$ The discount factor takes into account the value of money over time and is used to calculate net present value.

cost events for individual animals. The present values for each animal, $j$, were calculated using the following equation:

$$
\begin{aligned}
P V_{j}= & \Sigma d_{i} \times\left(M_{i j}+F_{i j}+P_{i j}-C_{i j}-I_{i j}\right. \\
& \left.-B_{i j}-A_{i j}+V_{i j}+O_{i j}\right),
\end{aligned}
$$

where $P V_{\mathrm{j}}=$ the present value of monthly net returns to animal $j ; d_{i}=$ the discount factor in month $i ; M_{i j}$ $=$ the value of milk sold in month $i$ from animal $j ; F_{i j}$ $=$ the value of milk fat sold in month $i$ from animal $j$; $P_{i j}=$ the value of milk protein sold in month $i$ from animal $j ; C_{i j}=$ the feed cost for animal $j$ in month $i ; I_{\mathrm{ij}}$ $=$ the cost of induced lactation treatment for animal $j$ in month $i ; B_{i j}=$ the cost of bST treatment for animal $j$ in month $i ; A_{i j}=$ the cost of artificial insemination for animal $j$ in month $i ; V_{i j}=$ the value of animal $j$ at the end of its participation in the trial in month $i$; and $O_{i j}$ $=$ the value of the offspring of animal $j$ in month $i$.

Economic values used in the present study (Table 2) were based on current market values and rates at the time of the study or were calculated based on cost of materials and labor. The value of milk was calculated by multiplying monthly production by the producer price differential (PPD) less hauling costs [USDAAgricultural Marketing Service (AMS), 2010]. Calves born alive were assigned a value of $\$ 100 /$ head. The value of cull animals was based on $\mathrm{BW}$ and a price of $\$ 0.88 / \mathrm{kg}$. Cows sold for dairy purposes were credited for the actual sale value. Animals culled after 60 mo of age were assigned a salvage value of $\$ 600$ at 60 mo of age. The calculated net present values (NPV) were compared statistically using Proc Mixed in SAS. The model statement was NPV = experimental group, where experimental group represented induced or peer animals.

The herd survival analysis was conducted 2 waysby animal age and productive life. Productive life was defined as the time in months from first milking to culling. The animals were followed throughout their lifetimes until no induced or peer animals remained in the herd. The data were analyzed using Proc PHREG in SAS. The model statement was cull date = group, where group represented induced or peer animals. Survival curves were compared and plots were generated using Proc LIFETEST in SAS where the time factor was cull date.

\section{RESULTS}

\section{Growth, Reproduction, and Production of Heifers Induced into Lactation}

Heifers induced into lactation averaged 301 DIM and produced 5,329 $\pm 1,538 \mathrm{~kg}$ milk (mean $\pm \mathrm{SD}$, Table 3). Peak milk yield of $22.7 \mathrm{~kg} / \mathrm{d}$ was attained at d 175 of lactation. Milk fat and protein percentages across lactation were 3.68 and $3.35 \%$, respectively, and are in the normal range for Holstein cows. Heifers averaged $74 \mathrm{~d}$ to first service, $102 \mathrm{~d}$ from start of milking to pregnancy (days "open") and calved at 27.9 mo of age. Twenty-seven of the 31 heifers induced into lactation calved. Mean calving ease score on a scale of 1 (no assistance) to 5 (Cesarean) was 2.2. Four heifers were culled during the induced lactation, one each for reproduction, mastitis, slow milking time, and injury due to accident. Data for all animals, including those culled, were used in statistical analyses. Mean BW of heifers during the induced lactation (Figure 1) reflected an average daily gain of $0.69 \pm 0.18 \mathrm{~kg}$ (mean $\pm \mathrm{SD}$ ) over the 9-mo period.

\section{Response to bST}

Heifers induced into lactation that received bST produced $14.7 \%$ more milk than did controls over the 70 -d treatment period $(P<0.05$; Figure 2; Table 4$)$. For both bST and control treatment groups, milk production increased over time $(P<0.01$, Figure 2$)$. Milk composition and SCC were similar for bST-treated and control heifers. Milk fat and protein concentrations averaged 3.66 and $3.28 \%$, respectively, during the $70-\mathrm{d}$ treatment period (Table 4).

\section{Heifers Induced into Lactation Versus Conventionally Raised Peer Heifers}

Four heifers induced into lactation and 7 peer heifers were culled during the experimental period that en- 


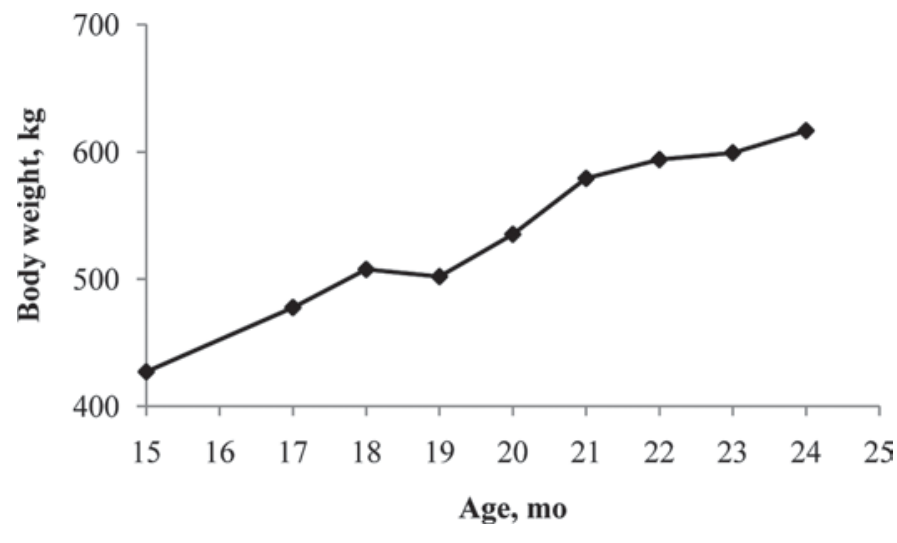

Figure 1. Body weights of heifers induced into lactation at $15 \mathrm{mo}$ of age. Body weights were measured monthly except for mo 16 when heifers were confined for induction. Average daily gain over this period was $0.69 \pm 0.18 \mathrm{~kg}$.

compassed the time from 15 mo of age until the end of the first lactation and subsequent calving (Table 5). Services per heifer for all animals were similar for animals induced into lactation (2.0) and peer heifers (1.7). Likewise, services per pregnancy for pregnant animals were similar for induced (1.8) and peer (1.7) heifers. Twenty-seven of the 31 heifers induced into lactation calved following the induced lactation, and 29 of the 31 peer heifers calved for their first lactations. The heifers induced into lactation were older at first calving versus peer animals $(P<0.01)$. Mean age at first calving was 24.5 mo for peer heifers and 27.9 mo for animals induced into lactation. Calving ease scores were similar for all animals, averaging 2.1 on a scale of 1 to $5(1=$ no assistance, $5=$ Cesarean). The percent calf mortality was $10 \%$ for the animals induced into lactation and $23 \%$ for the peers, but was not significantly different.

\section{Herd Survival and Economic Value}

The survival distribution function revealed that the animals induced into lactation had a $62.7 \%$ chance of surviving as long as the peers (Figure 3a) in the dairy herd (hazard ratio $=0.627, P=0.07$ ). Productive herd life was similar for heifers induced into lactation and peer heifers. The heifers induced into lactation had a productive herd life $90.5 \%$ as long as that of the peers (Figure 3b), and they were not statistically different (hazard ratio $=0.905, P=0.71$ ). Heifers induced into lactation averaged $2.7 \pm 1.2$ lactations, while peer heifers had $2.5 \pm 1.9$ lactations (means $\pm \mathrm{SD}$ ).

The total amount of milk produced by the heifers induced into lactation was greater than that produced by the peers until 45 mo of age (Figure 4 ). Thereafter the peers, as a group, produced more milk than did the group of heifers induced into lactation. Net present value for animals induced into lactation averaged $\$ 2,459$, while that of peer animals was $\$ 3,137$. However, given the variation among animals, the NPV difference was not statistically significant $(\mathrm{SE}=322, P=0.14)$.

\section{DISCUSSION}

Heifers induced into lactation were healthy and produced well, considering their young age and size at the onset of milking. Lactations averaged $301 \mathrm{~d}$ and mean total milk production was $5,329 \mathrm{~kg}$. While this is less than the average first lactation milk yield for postpartum animals in the Penn State herd, this level of milk production is considerable for young heifers that otherwise would not be lactating. Bovine somatotropin increased milk yields in heifers hormonally induced into lactation, much like that observed in postpartum animals (Bauman et al., 1999) and older cows induced to lactate (Magliaro et al., 2004). Milk yield responses to bST were similar for primiparous and multiparous cows, and gradually increased over time and reached a plateau (Bauman et al., 1999). In the present study, the milk yield response to bST increased over time. While the mean increase in production over the $70-\mathrm{d}$ treatment period was $14.7 \%$, mean daily milk production was $21.8 \%$ higher in bST-treated heifers than in controls at the end of the 70-d treatment period. If the bST versus control treatment had continued beyond the 70-d comparison period used in the present study, it is possible that the milk yield response would have been even greater.

Table 3. Growth, reproduction, and milk production of heifers induced into lactation ${ }^{1}$

\begin{tabular}{lcc}
\hline Item & Mean & SD \\
\hline Milk yield to 305 d, kg & 4,913 & 1,208 \\
Total milk yield, kg & 5,329 & 1,538 \\
DIM & 301 & 67 \\
Peak milk yield, kg/d & 22.7 & 4.0 \\
Days to peak milk yield & 175 & 61 \\
Milk fat, \% & 3.68 & 0.41 \\
Milk protein, \% & 3.35 & 0.20 \\
ADG, ${ }^{2}$ kg $(\mathrm{n}=27)$ & 0.69 & 0.18 \\
Days to 1st service & 74 & 29 \\
Days open & 102 & 59 \\
Age at 1st calving, mo $(\mathrm{n}=27)$ & 27.9 & 1.9 \\
Calving ease score $(\mathrm{n}=26$ of 27$)$ & 2.1 & 1.1 \\
\hline
\end{tabular}

${ }^{1} \mathrm{n}=31$ unless otherwise noted. All heifers were induced into lactation at 15 mo of age. Sixteen heifers received bST for $70 \mathrm{~d}$ beginning on d $25 \pm 7$ of lactation, while 15 heifers did not receive bST during this period. All of the heifers induced into lactation $(n=31)$ received bST after 95 DIM, and this continued throughout the remainder of lactation.

${ }^{2}$ Average daily gain (ADG) was calculated over a 9-mo period beginning with the onset of lactation induction.

${ }^{3}$ Represents the number of days from first milking to conception. 
Table 4. Effect of bST on yield and composition of milk from heifers induced into lactation ${ }^{1}$

\begin{tabular}{lcccc}
\hline Component & bST & Control & SE & $P$-value, $<$ \\
\hline Milk yield, kg/d & 17.9 & 15.6 & 0.62 & 0.01 \\
Fat, \% & 3.65 & 3.67 & 0.16 & NS \\
Protein, \% & 3.28 & 3.27 & 0.07 & NS \\
SCC, $\times 1,000$ & 186 & 399 & 193 & NS \\
\hline
\end{tabular}

${ }^{1}$ The bST vs. control treatments were compared over a 70 -d period beginning on d $25 \pm 7$ of lactation with 16 and 15 heifers in the bST and control treatment groups, respectively. Milk production was measured daily, and a significant treatment $\times$ time interaction was observed $(P$ $<0.01$ ). For analysis of milk composition, 2 milk samples collected at $30-d$ intervals were used.

Milk composition was similar between bST-treated and control animals. Cows induced into lactation also had similar milk fat and protein concentrations during bST treatment compared with that of animals induced into lactation and not treated with bST (Magliaro et al., 2004). Likewise, milk composition of postpartum cows in positive energy balance treated with bST was similar to that in untreated controls (Bauman, 1992). Milk fat and protein concentrations for the heifers induced into lactation averaged 3.68 and $3.35 \%$, respectively, over their entire first lactations. This is higher than the 3.46 and $3.21 \%$ fat and protein observed for primiparous cows at the Penn State Dairy Cattle Research and Teaching Center during the time the present study was conducted. Thus, the heifers induced into

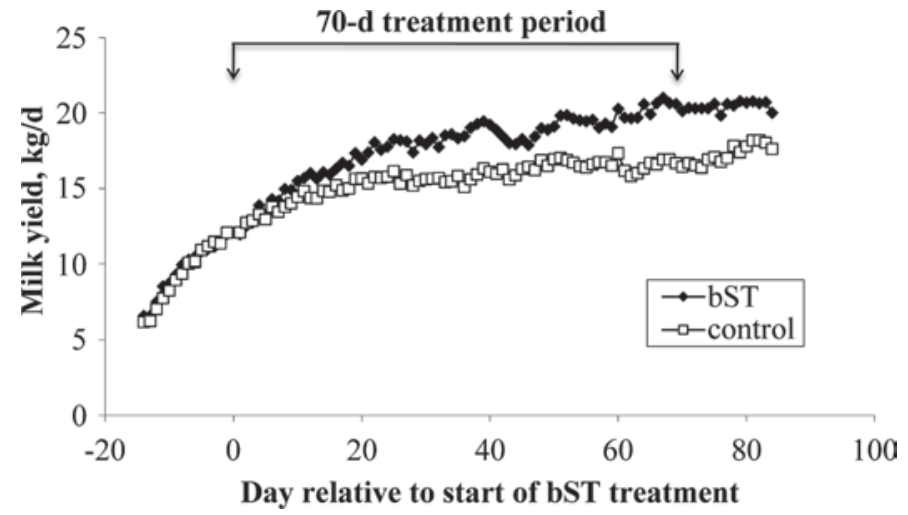

Figure 2. Comparison of milk yields of heifers induced into lactation and treated with bST with heifers induced into lactation and not treated with bST (control). The 70-d bST treatment period began on d $25 \pm 7$ of lactation. Pooled SE $=0.62$.

lactation produced milk with higher solids content and, consequently, a higher economic value per unit of milk produced. Previous research has shown that cows and heifers induced into lactation typically have milk fat and protein percentages higher than those observed in postpartum animals (Parkes and Glover, 1944; Banica and Teodoru, 1962; Erb et al., 1976; Davis et al., 1983; Magliaro et al., 2004).

In the present study, heifers induced into lactation exhibited a gradual increase in milk yield and did not reach peak production until $175 \pm 61 \mathrm{~d}$ of lactation.

Table 5. Reproductive performance, health, and culling reasons for heifers induced into lactation and their cohort peer heifers $(\mathrm{n}=31 \text { in each })^{1}$

\begin{tabular}{|c|c|c|c|c|}
\hline Item & $\begin{array}{l}\text { Induced } \\
\text { heifers }\end{array}$ & $\begin{array}{c}\text { Peer } \\
\text { heifers }\end{array}$ & $\mathrm{SE}$ & $P$-value, $<$ \\
\hline Culled during experimental period $^{2}$ & 4 & 7 & & \\
\hline \multicolumn{5}{|l|}{ Prior to lactation } \\
\hline Reproductive failure & $\mathrm{n} / \mathrm{a}^{3}$ & 2 & & \\
\hline \multicolumn{5}{|l|}{ During first lactation } \\
\hline Reproductive failure & 1 & 2 & & \\
\hline Injury & 1 & & & \\
\hline Mastitis & 1 & & & \\
\hline Slow milking & 1 & & & \\
\hline Postcalving disorders & $\mathrm{n} / \mathrm{a}$ & 2 & & \\
\hline Infection & $\mathrm{n} / \mathrm{a}$ & 1 & & \\
\hline Services/heifer, all heifers ${ }^{4}$ & 2.0 & 1.7 & 0.3 & NS \\
\hline Services/pregnancy, pregnant heifers ${ }^{4}$ & 1.8 & 1.7 & 0.2 & NS \\
\hline Number that calved & 27 & 29 & & \\
\hline Age at first calving & 27.9 & 24.5 & 0.3 & 0.01 \\
\hline BCS at calving & 3.7 & 3.9 & 0.1 & 0.05 \\
\hline Calving ease score & 2.1 & 2.1 & 0.3 & NS \\
\hline Calf mortality, \% (no. born dead/no. born) & $10(3 / 30)$ & $23(7 / 30)$ & & NS \\
\hline
\end{tabular}

${ }^{1}$ A peer heifer cohort was selected for each induced heifer based on similar date of birth. To be selected, all peer heifer cohorts had to be in the herd at the time the induced lactation experiment began.

${ }^{2}$ The experimental period encompassed the time heifers were induced into lactation through the end of the first lactation and subsequent calving.

${ }^{3}$ Not applicable.

${ }^{4}$ The number of services reported are those attempting to achieve a first pregnancy. Induced heifers (heifers induced into lactation) were lactating; peer heifers were not lactating. 
a)

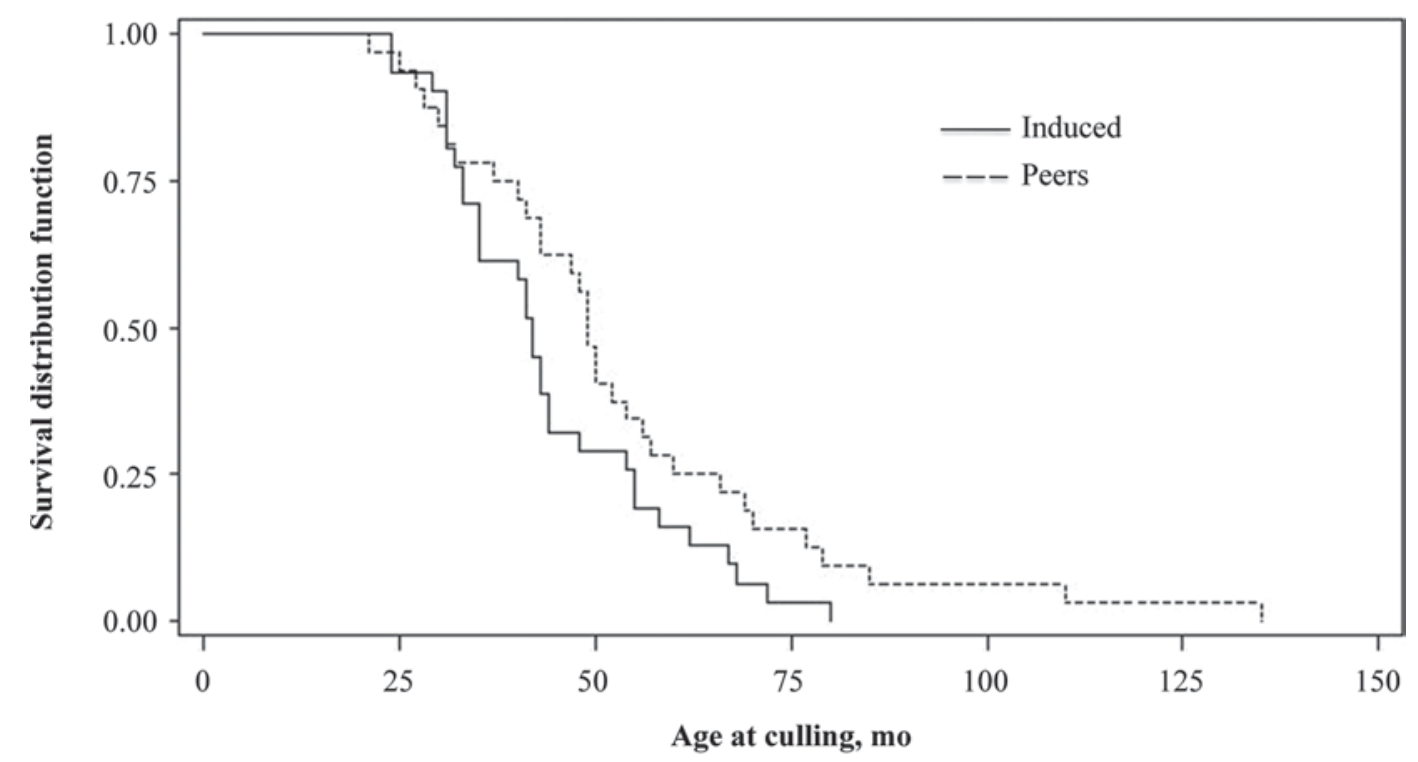

b)

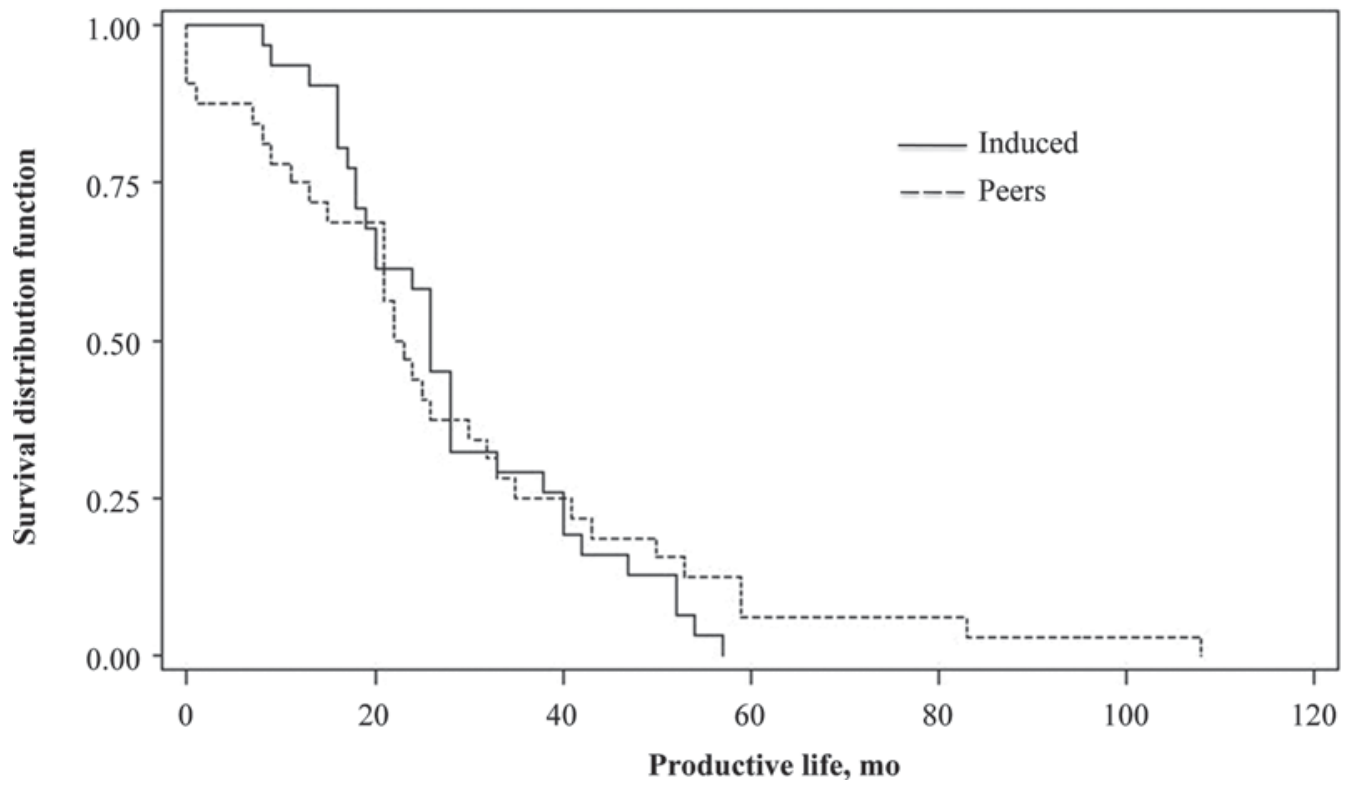

Figure 3. Herd survival distribution functions for heifers induced into lactation at 15 mo of age and peer cohorts that were reared by traditional management methods. A peer heifer cohort was selected for each induced heifer based on a similar date of birth. After the initial induced lactation, all animals were managed according to standard herd management protocols and followed for a herd life. a) The survival curves based on age. Animals induced into lactation had a $62.7 \%$ chance of surviving as long as the peers (hazard ratio $=0.627, P=0.07$ ). b) Survival curves based on length of productive life defined as time in months from first milking to culling. Heifers induced into lactation had a productive life $90.5 \%$ as long as the peers; however, this was not statistically different (hazard ratio $=0.905, P=0.71$ ).

Previous studies on induced lactation also have shown this slow increase in milk yield and longer time to reach peak production (Smith and Schanbacher, 1973, 1974; Collier et al., 1975; Erb et al., 1976; Collier et al., 1977; Bel Isle and Swanson, 1978; Kensinger et al., 1979; Jordan et al., 1981; Fowler et al., 1991; Magliaro et al., 2004). However, this appears to be a longer time to peak production than the $125 \pm 47 \mathrm{~d}$ observed in mature cows induced into lactation (Magliaro et al., 2004). The heifers induced into lactation in the present study were growing throughout lactation and, hence, were increasing their feed intake capacity. Also, mammary gland development may have continued for a longer period of time in heifers versus mature cows induced 
into lactation. Overall, the heifers induced into lactation appeared to make the transition to lactation easily. They did not appear to experience a period of negative energy balance and maintained sufficient feed intake to support lactation and good growth rates.

In addition to growth rates within the normal range for heifers of this age (Heinrichs and Lammers, 1998), heifers induced into lactation also had reproductive performance similar to that of the peer heifers, which were not lactating at the time of first breeding. This is notable, considering that the animals induced into lactation were lactating and became pregnant at approximately $18 \mathrm{mo}$ of age. Twenty-seven of the 31 heifers induced into lactation calved at an average age of 28 mo following induced lactation. Age at first calving was higher for animals induced into lactation compared with peer heifers, which calved at 24.5 mo. The 3.5 -mo difference was due to the delayed breeding of the heifers induced into lactation. Breeding of peer heifers began at $15 \mathrm{mo}$, the same age when the induction protocol began for the heifers induced into lactation.

The heifers induced into lactation had no mitigating problems that required culling in the period immediately after the onset of lactation. During the period from the start of the experiment through the first lactation, cull rates for heifers induced into lactation and peer animals were 12.9 and $22.6 \%$, respectively. The peer animal cull rate is similar to the national cow cull rate of $23.6 \%$, as reported by NAHMS (2007). The lower cull rate experienced by the animals induced into lactation is likely due to lack of postcalving disorders.

The animals induced into lactation had a shorter herd life compared with the peer cohorts, but both groups had similar productive herd lives. This reinforces the concept that culling in this age group is usually due to lactation- or calving-related issues, and not due to age itself. The heifers induced into lactation in the present study started milking at a younger age and were, therefore, susceptible to mastitis and decreased fertility at a younger age.

We did not statistically compare milk production during the induced lactation and the peer heifers' first lactation. The animal ages and time of lactation onset were vastly different, and a comparison may not be meaningful. Milk yield and composition data by lactation is presented for the reader's information (Table 6 ). It is clear, though, that the heifers induced into lactation started producing milk well in advance of the peer animals, but the peers catch up and surpass the animals induced into lactation over time (Figure 4). The economic analysis was performed to determine if the earlier generation of income was more profitable than selling a greater amount of milk at a later time. Net present value analysis was used because it accounts

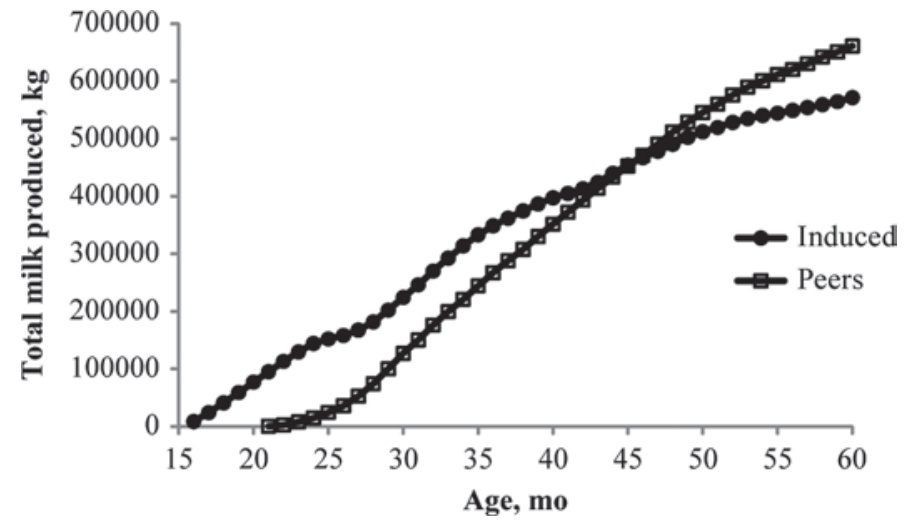

Figure 4. Total milk produced by heifers induced into lactation at 15 mo of age and peer cohorts that were reared by traditional management methods. A peer heifer cohort was selected for each induced heifer based on similar date of birth. After the initial induced lactation, all animals were managed according to standard herd management protocols and milk production data were collected through 60 mo of age.

for the value of money over time, so one can equitably compare streams of money over time. The mean NPV was numerically higher for the peer animals compared with that of the heifers induced into lactation by $\$ 678$, but this difference was not significant. However, the NPV calculations did not take into account other economic factors, such as facility utilization and other capital considerations. It must be appreciated that if the heifers were in a typical herd where they were not induced into lactation, then capital would be required for housing them outside the milking herd barn and the producer has nonproductive animals in costly housing. This implies that the NPV differences presented are the upper limits to the differences in economic returns due to induced lactation.

The total milk produced up to 60 mo of age by the heifers induced into their first lactation was less than that produced by the peers, and the earlier generation of income was not enough to offset the lower overall milk production. While some traditionally reared heifers may be lost before first lactation, our results indicate that there is no economic advantage associated with inducing lactation with the protocol used in the present study. The higher production of the traditionally reared animals was enough to compensate for the heifers lost before first calving. Lormore and Galligan (2001) estimated that induced lactation in heifers would be profitable if milk yields were $79 \%$ of expected production. Primiparous cows in the Penn State herd at the time of the study produced approximately $11,080 \mathrm{~kg}$ in their first lactations. At 5,329 kg, the heifers induced into lactation produced only $48 \%$ of the expected milk yield. However, we lack information on how to manage 
Table 6. Milk yield and composition by lactation for heifers induced into their first lactation and their peer heifer cohorts ${ }^{1}$

\begin{tabular}{|c|c|c|c|c|c|c|}
\hline Lactation & $\mathrm{n}$ & $\begin{array}{l}\text { Milk } \\
\text { yield, } \mathrm{kg}\end{array}$ & $\begin{array}{l}305 \mathrm{ME}^{2} \text { milk } \\
\text { yield, } \mathrm{kg}\end{array}$ & $\begin{array}{c}\text { Fat, } \\
\%\end{array}$ & $\begin{array}{c}\text { Protein, } \\
\quad \%\end{array}$ & DIM \\
\hline \multicolumn{7}{|c|}{$\begin{array}{l}\text { Heifers induced into lactation } \\
\text { (for lactation } 1 \text { only })^{3}\end{array}$} \\
\hline 2 & 26 & $8,592 \pm 3,243$ & $10,924 \pm 1,457$ & $3.48 \pm 0.43$ & $3.17 \pm 0.17$ & $277 \pm 93$ \\
\hline 3 & 15 & $9,191 \pm 5,432$ & $11,607 \pm 2,650$ & $3.46 \pm 0.46$ & $3.05 \pm 0.17$ & $250 \pm 174$ \\
\hline 4 & 5 & $10,038 \pm 5,954$ & $11,191 \pm 1,237$ & $3.76 \pm 0.24$ & $2.89 \pm 0.17$ & $284 \pm 174$ \\
\hline 1 & 29 & $11,111 \pm 4,369$ & $11,912 \pm 1,465$ & $3.55 \pm 0.65$ & $3.22 \pm 0.22$ & $332 \pm 99$ \\
\hline 2 & 25 & $10,716 \pm 4,467$ & $12,099 \pm 1,959$ & $3.26 \pm 0.45$ & $3.03 \pm 0.23$ & $283 \pm 109$ \\
\hline 3 & 11 & $11,684 \pm 2,514$ & $12,396 \pm 1,575$ & $3.40 \pm 0.29$ & $2.98 \pm 0.24$ & $294 \pm 61$ \\
\hline 4 & 8 & $11,328 \pm 7,662$ & $11,464 \pm 3,708$ & $3.78 \pm 0.76$ & $2.88 \pm 0.20$ & $280 \pm 164$ \\
\hline
\end{tabular}

${ }^{1}$ Values are means \pm standard deviations.

${ }^{2}$ Mature equivalent.

${ }^{3}$ Heifers were induced into their first lactation at 15 mo of age. First milking occurred at 15.6 mo of age. Lactations 2 to 4 were postpartum lactations.

${ }^{4}$ Not applicable.

${ }^{5}$ A peer heifer cohort was selected for each heifer induced into lactation based on similar date of birth. All lactations were postpartum. First calving and onset of first lactation occurred at $24.5 \pm 0.3$ mo of age.

heifers induced into lactation in order to maximize milk production. The heifers induced into lactation in the present study were managed in a similar manner to postpartum cows, and this may not be optimal for milk production.

The present study is unique in that it is the first to report herd life survival rates and an economic analysis comparing heifers hormonally induced into their first lactation to traditionally reared animals. Inducing heifers into lactation at 15 mo of age as a regular management tool did not have any economic advantage in this study. However, other uses for induced lactation may exist in dairy cattle. Induced lactation may be of value for saving good animals with high genetic merit, or in evaluation of transgenic animals at an earlier age (Ball et al., 2000; Kensinger and Magliaro, 2002). Currently, induced lactation is not approved by the FDA for commercial use. Some researchers have proposed using the mammary gland as a bioreactor to produce proteins for therapeutic use. Transgenic animals have been shown to secrete human lactoferrin, growth hormone, albumin, collagen (cow), human protein $\mathrm{C}$ (sow), human erythropoietin (sow), tissue plasminogen activator (sheep), recombinant clotting factor IX (sheep), and recombinant antithrombin III (goats) in their milk. Many of these proteins are currently in preclinical, phase 2, or phase 3 development (Houdebine, 2009; Chaible et al., 2010). If these products are FDA approved, the protein-producing transgenic animals may have considerable monetary value. Induced lactation may provide a means to obtain milk without the potential complications associated with pregnancy and parturition.

\section{CONCLUSIONS}

Young heifers hormonally induced into lactation with estrogen and progesterone were healthy, grew normally, produced milk with normal composition starting 10 mo before calving, and had similar reproductive performance compared with non-induced peer animals. Those treated with bST produced more milk than non-bSTtreated controls. Heifers induced into lactation had a similar productive lifespan compared with that of peers but produced less milk through 60 mo of age than did traditionally reared heifers. Therefore, hormonally induced lactation of 15-mo-old heifers was not more profitable than traditional management practices.

\section{ACKNOWLEDGMENTS}

This work was supported by Hatch funds and by USDA special grant no. 96-34281-3028 to R. S. Kensinger. The authors thank Missy Klepfer, Andy Demma, Eric Penrod, Mark Amsler, Virginia Ishler, Nadine Houck, and other colleagues at the Penn State Dairy Research and Education Center (University Park, PA) for their contributions.

\section{REFERENCES}

Ball, S., K. Polson, J. Emeny, W. Eyestone, and R. M. Akers. 2000. Induced lactation in prepubertal Holstein heifers. J. Dairy Sci. 83:2459-2463.

Banica, G., and V. Teodoru. 1962. Milk production of cattle with reestablished reproductive function following artificially induced lactation. Stud. Cercet. Endocrinol. 13:813-814.

Bauman, D. E. 1992. Bovine somatotropin: Review of an emerging animal technology. J. Dairy Sci. 75:3432-3451. 
Bauman, D. E., R. W. Everett, W. H. Weiland, and R. J. Collier. 1999 Production responses to bovine somatotropin in northeast dairy herds. J. Dairy Sci. 82:2564-2573.

Bel Isle, D. M., and L. Swanson. 1978. Effect of calf contact on hormonally induced lactation. J. Dairy Sci. 61:509-512.

Byatt, J. C., P. J. Eppard, J. J. Veenhuizen, T. L. Curran, D. F. Curran, M. F. McGrath, and R. J. Collier. 1994. Stimulation of mammogenesis and lactogenesis by recombinant bovine placental lactogen in steroid-primed dairy heifers. J. Endocrinol. 140:33-43.

Byatt, J. C., R. H. Sorbet, P. J. Eppard, T. L. Curran, D. F. Curran, and R. J. Collier. 1997. The effect of recombinant bovine placental lactogen on induced lactation in dairy heifers. J. Dairy Sci. 80:496-503.

Chaible, L. M., M. A. Corat, E. Abdelhay, and M. L. Dagli. 2010. Genetically modified animals for use in research and biotechnology. Genet. Mol. Res. 9:1469-1482.

Collier, R. J., D. E. Bauman, and R. L. Hays. 1975. Milk production and reproductive performance of cows hormonally induced into lactation. J. Dairy Sci. 58:1524-1527.

Collier, R. J., D. E. Bauman, and R. L. Hays. 1977. Effect of reserpine on milk production and serum prolactin of cows hormonally induced into lactation. J. Dairy Sci. 60:896-901.

Davis, S. R., R. A. Welch, M. G. Pearce, and A. J. Peterson. 1983. Induction of lactation in nonpregnant cows by estradiol-17 beta and progesterone from an intravaginal sponge. J. Dairy Sci. $66: 450-457$.

Erb, R. E., E. L. Monk, T. A. Mollett, P. V. Malven, and C. J. Callahan. 1976. Estrogen, progesterone, prolactin and other changes associated with bovine lactation induced with estradiol-17beta and progesterone. J. Anim. Sci. 42:644-654.

Fowler, P. A., C. H. Knight, and M. A. Foster. 1991. In vivo magnetic resonance imaging studies of mammogenesis in non-pregnant goats treated with exogenous steroids. J. Dairy Res. 58:151-157.

Fulkerson, W. J. 1978. Artificial induction of lactation: A comparative study in heifers. Aust. J. Biol. Sci. 31:65-71.

Harness, J. R., R. R. Anderson, L. J. Thompson, D. M. Early, and A. K. Younis. 1978. Induction of lactation by two techniques: Success rate, milk composition, estrogen and progesterone in serum and milk, and ovarian effects. J. Dairy Sci. 61:1725-1735.

Heinrichs, J., and B. Lammers. 1998. Monitoring dairy heifer growth. Cooperative Extension publication. The Pennsylvania State University, University Park, PA.

Heinrichs, J. 1996. The importance of heifer raising to a profitable dairy farm. Pages 1-6 in Proc. Calves, Heifers, and Dairy Profitability National Conference, Harrisburg, PA. NRAES-74.

Houdebine, L. M. 2009. Production of pharmaceutical proteins by transgenic animals. Comp. Immunol. Microbiol. Infect. Dis. $32: 107-121$.
Jordan, D. L., R. E. Erb, P. V. Malven, C. J. Callahan, and E. L. Veenhuizen. 1981. Artificial induction of lactation in cattle: Effect of modified treatments on milk yield, fertility, and hormones in blood plasma and milk. Theriogenology 16:315-329.

Kensinger, R. S. 2000. Induced lactation: Physiology, perception, profitability and propriety. J. Dairy Sci. 83(Suppl. 1):23. (Abstr.)

Kensinger, R. S., D. E. Bauman, and R. J. Collier. 1979. Season and treatment effects on serum prolactin and milk yield during induced lactation. J. Dairy Sci. 62:1880-1888.

Kensinger, R. S., and A. L. Magliaro. 2002. Induced Lactation. Pages 1447-1452 in Encyclopedia of Dairy Sciences. Vol. 3. H. Roginski, J. W. Fuquay, and P. F. Fox, ed. Academic Press, New York, NY.

Lormore, M. J., and D. T. Galligan. 2001. Economics of atypical lactation. J. Dairy Sci. 84:E212-E215.

Magliaro, A. L., R. S. Kensinger, S. A. Ford, M. L. O'Connor, L. D. Muller, and R. Graboski. 2004. Induced lactation in nonpregnant cows: Profitability and response to bovine somatotropin. J. Dairy Sci. 87:3290-3297.

Malpress, F. H. 1947. Experimental induction of lactation. Br. Med. Bull. 5:161-163.

National Animal Health Monitoring System (NAHMS). 2007. Highlights of dairy 2007 part I: Reference of dairy cattle health and management practices in the United States, 2007. USDA:Animal and Plant Health Inspection Service (APHIS), Washington, DC.

NRC. 1989. Nutrient Requirements of Dairy Cattle. 6th rev. ed. Natl Acad. Sci., Washington, DC.

Parkes, A. S., and R. E. Glover. 1944. Induction of lactation in heifers by a single injection of esters of diethylstilboestrol. J. Endocrinol. 4:90-102.

Peel, C. J., J. W. Taylor, I. B. Robinson, A. A. McGowan, R. D Hooley, and J. K. Findlay. 1978. The importance of prolactin and the milking stimulus in the artificial induction of lactation in cows. Aust. J. Biol. Sci. 31:187-195.

Smith, K. L., and F. L. Schanbacher. 1973. Hormone induced lactation in the bovine. I. Lactational performance following injections of 17b-estradiol and progesterone. J. Dairy Sci. 56:738-743.

Smith, K. L., and F. L. Schanbacher. 1974. Hormone induced lactation in the bovine. II. Response of nulligravida heifers to modified estrogen-progesterone treatment. J. Dairy Sci. 57:296-303.

USDA-Agricultural Marketing Service (AMS). 2010. Announcement of Class and Component Prices. Accessed July 2, 2010. http://www. fmmone.com/Northeast_Order_Prices/NE_Prices_main_new. htm\#Component.

Walker, S. M., and A. J. Stanley. 1941. Effect of diethylstilbestrol on mammary development and lactation. Proc. Soc. Exp. Biol. Med. 48:50-53. 